\title{
FOREIGN AID AND ECONOMIC GROWTH IN SOUTH AFRICA: AN EMPIRICAL ANALYSIS USING BOUNDS TESTING
}

\author{
Temitope Leshoro* \\ University of South Africa \\ lesholat@unisa.ac.za
}

April 2012

\begin{abstract}
South Africa is classified as one of the wealthiest countries in Africa, yet half of its population lives below the poverty line and over a quarter of its labour force is unemployed. Foreign aid was one of the major sources of capital for the country. It poured in from many developed countries and it was very successful in promoting a stable society, especially during the first few years after apartheid ended in 1994. Thus, South Africa is a good case study for determining the relationship between and the effect of foreign aid on growth. The data on aid flow as a percentage of gross domestic product (GDP) in South Africa was only available from 1980, thus limiting the data from 1980 to 2009. Given the limitations in the data, a co-integration analysis of the autoregressive distributed lag (ARDL) was adopted, using the method of the conditional unrestricted error correction model (UECM), which accommodates small samples. The result shows that the relationship between aid and growth is negative both in the short and the long run.
\end{abstract}

Keywords

Foreign aid; gross domestic product; ARDL; UECM

*Mrs Temitope Leshoro is a senior lecturer in the Economics Department, University of South Africa (UNISA), South Africa. 


\section{INTRODUCTION}

South Africa is classified as one of the richest countries in Africa, with a gross domestic product (GDP) per capita of almost double that of Egypt and about four times that of Ghana, as estimated in 2011 (CIA, 2012). However, a large number of its population lives below the poverty line and over a quarter of its labour force is unemployed (May, 2006). One of the main sources of capital for the country is foreign aid, where a yearly net of about US\$460.4 and US\$486 million of total overseas or official development assistance (ODA) was received in 2004 and 2005, respectively (May, 2006; 0ECD, 2006; 0ECD, 2007). The purpose of foreign aid is to reduce the problem of inequalities in global income. Has this goal been achieved, especially in the case of South Africa?

Since South Africa has been receiving foreign aid for a long time, and many of its population are still living in abject poverty, the question remains whether foreign aid has any impact on the per capita GDP of the country as one of the measures of economic growth. In 1995, South Africa was the second largest African country, after Egypt, to receive US aid (0ECD, 1997). Despite the considerable development assistance received compared with many developing countries, foreign aid was about $1 \%$ of the state budget and $0.3 \%$ of the GDP (CMI, 2003). The objective of this study is, therefore, to determine the relationship between foreign aid and the growth rate of GDP per capita and to determine whether it is positive, negative or statistically significant. A further objective is to investigate if there is a long-run relationship between these variables and, therefore, to determine the effect of foreign aid on growth both in the short and the long run.

During the first few years after apartheid ended in South Africa in 1994, there was a huge inflow of foreign aid that was expected to assist in promoting a stable society. Some of the objectives of this aid were a reduction in child mortality, promotion of gender equality and empowerment of women and maternal health improvement (May, 2006; UNDP, 2010). Aid poured in from many developed countries, such as the United States, United Kingdom, Germany, France and Denmark, to mention but a few of the top 10 donors to South Africa (OECD, 2010).

Other Development Assistance Committee (DAC) donors include Australia, Austria, Finland, Ireland, Norway and Sweden, and some of the multilateral donors are European Union (EU) institutions, the United Nations International Children's Emergency Fund (UNICEF - now United Nations Children's Fund), the Global Fund, the International Monetary Fund (IMF) and the United Nations Development Programme (UNDP) (OECD, 2010). Since the inception of foreign aid in 1961, the DAC has collected data on its aid to all recipient countries. Aid to South Africa started many years later. For instance, USAID began to flow into the country in 1986, although earlier efforts started in 1979 (USAID, 2010). South Africa was only added to the list of ODA recipients in 1991 (OECD, 2010).

During the first few post-apartheid years, donor countries chose specific institutional targets for their aid and this was successful because aid was used solely for changing existing institutions as well as building a new system of governance. However, aid used generally in targeting poverty achieved less. As the period of post-apartheid crisis decreased, donors began to seek other objectives, such as, promoting overall economic growth, and aid money was not targeted towards specific goals (May, 2006). 
Literature on the theoretical link between aid and economic growth is discussed in the next section, and section 3 deals with the methodology and data. The results are provided in section 4 , and section 5 concludes the study.

\section{THEORETICAL LINK BETWEEN AID AND ECONOMIC GROWTH}

Several studies have been carried out on the relationship between foreign aid and economic growth and various results have been obtained. While some studies revealed a positive relationship between these variables (Hansen and Tarp, 2000; Hatemi-J and Irandoust, 2005; Moreira, 2005; Karras, 2006), a negative relationship was found by others (Brautigam and Knack, 2004; Feeny, 2005; Mallik, 2008) and a mixed relationship by others (Islam, 1992; Ekanayake and Chatrna, 2010). Some of these studies are reviewed below.

Hatemi-J and Irandoust (2005) investigated the relationship between foreign aid and economic growth in six developing countries, namely Botswana, Kenya, Tanzania, Sri Lanka, Ethiopia and India. These countries are the major recipients of aid from Sweden. Due to the limited data available, the period reviewed was 1974 to 1996. The log of real GNP per capita was used to measure economic growth for each country and panel co-integration analysis was adopted to determine the long-run relationship. The results showed a positive and significant relationship between foreign aid and growth, where the country-specific elasticity for most countries is close to 1 .

In addition, using the generalised method of moments (GMM) to determine the relationship between aid and economic growth, Moreira (2005) found a positive relationship for 48 developing countries over the period 1970 to 1998. After making a minor change to the HarrodDomar growth equation, the economic growth was measured using the real GDP per capita in order to integrate the effects of population growth. A non-linear relation between aid and growth was used, where not only the variable aid was included, but also its square term in order to account for the inverted $U$-shaped relationship that was believed to exist between aid and economic growth. Other variables considered were share of domestic savings to GDP, the ratios of private flow to GDP and other official flow to GDP, population growth and other growth determinants. The results also showed that the effect of aid on growth is higher in the long run than in the short run.

On the other hand, Feeny (2005) carried out a study to measure the impact of foreign aid on the growth of GDP in Papua New Guinea, over the period 1965 to 1999. The analysis disaggregated foreign aid into different components. This was done to investigate the effect of different types of foreign aid on GDP growth. In general, there was no evidence that total foreign aid positively contributes to the growth of the economy, although the relationship between these variables is not robust. However, aid provided in the form of projects has a positive impact on growth. The effect of aid on growth was found to be most prevalent during the structural adjustment periods. Mbaku (1994) also used both total and disaggregated aid models to determine the effect of aid on growth in Cameroon, using data from 1971 to 1990. The result showed that there was no significant impact of foreign aid, whether aggregated or disaggregated, on growth.

Mallik (2008) examined the effect of foreign aid on six of the poorest African countries, which are heavily dependent on foreign aid. These countries and the data periods considered for each are Central African Republic: 1977 to 2004; Malawi: 1965 to 2005; Mali: 1965 to 2005; Niger: 1965 to 2005; Sierra Leone: 1970 to 2005 and Togo: 1980 to 2004. The co-integration method of 
analysis was used to find if there is a long-run relationship between foreign aid and economic growth, where real per capita GDP was used to measure growth. Other variables included were ratio of investment to GDP and openness, which was measured as exports plus imports as a percentage of GDP. The results showed a negative relationship between foreign aid and economic growth for most of these countries in the long run, although there was no significant effect of aid on growth in the short run, except for Niger.

However, Ekanayake and Chatrna (2010) found mixed effects of foreign aid on economic growth when they carried out a study on 85 developing countries, covering Asia, Africa, Latin America and the Caribbean over the period spanning 1980 to 2007. The growth rate of real GDP per capita as a measure of economic growth was regressed on several explanatory variables. Growth rate of population replaced the rate of change in labour input, ratio of investment to GDP was used as a proxy for growth rate of capita stock, and inflation rate, foreign aid and a square of foreign aid were the other variables considered for each country. The square term of aid was included as in the case of Moreira (2005). These researchers estimated three models, dividing them into different periods, regions and income levels.

Furthermore, in the study carried out by Islam (1992) on Bangladesh, the aggregate production function was used to test the effect of foreign aid on economic growth. Bangladesh is one of the poorest countries in the world receiving huge amounts of foreign aid. It was found that the aggregate foreign aid does not have any significant effect on economic growth. However, in its disaggregated form, each component is significant, but some are more significant than others. The problems identified in these mixed results are limitations in data, measurement and other econometric problems.

\section{METHODOLOGY AND DATA}

\subsection{Variable description and data sources}

The data on aid flow as a percentage of GDP in South Africa is available from 1980. Due to the limited data period, this paper reports on country-specific time series data from 1980 to 2009, constituting 25 observations. Conventionally, the model is derived from a production function where foreign aid is introduced as an input. Therefore, following the production function model used in estimating the effect of foreign aid on economic growth by earlier authors (Islam, 1992; Mbaku, 1994; Lloyd, Morrissey and Osei, 2001; Chatterjee and Turnovsky, 2007; Ekanayake and Chatrna, 2010), this was our point of departure for this study. However, the contribution of this study is the use of the autoregressive distributed lag ( $A R D L)$ method of co-integration in estimating both the short- and long-run effect of foreign aid on economic growth.

The variables considered in this study, as well as their sources, are explained below:

- Economic growth rate was measured using the growth rate of GDP per capita in current US dollars. The growth rate of GDP per capita was computed from the GDP per capita that was sourced from the World Bank World Development Indicators database.

- The data on the total labour force was from the same database, and growth rate was obtained by applying the natural logarithm.

- Gross capital formation (formerly gross domestic investment) as a percentage of GDP was obtained from the World Bank World Development Indicators database. 
- The data on total aid as a percentage of GDP was computed from the data on aid and GDP individually obtained from the Center for Global Development database.

\subsection{Model Specification}

The specification of the model, which explains the relationship between foreign aid and per capita GDP growth for South Africa, is discussed in this section. The ARDL framework was used to estimate the model. This model is suitable mainly when conducting co-integration analysis in small samples, as in this case. This is because it avoids the finite sample bias that static estimators are faced with, and it is more efficient than vector autoregressive (VAR) methods (Inder, 1993; Banerjee, Dolado, Galbraith and Hendry, 1993). Another advantage of ARDL is that where the variables are co-integrated, the single equation ARDL estimator gives highly consistent estimates of the long-run parameters and valid $t$-ratios, even in the presence of endogenous explanatory variables (Inder, 1993). The production function, which is assumed to be linear, is thus written as follows:

$$
\mathrm{Y}=f(\mathrm{~L}, \mathrm{~K}, \mathrm{~A})
$$

where $\mathrm{Y}$ is GDP in real terms, $\mathrm{L}$ is labour input, $\mathrm{K}$ is domestic capital stock and $\mathrm{A}$ is foreign aid stock.

Using the natural logarithm and differencing $\varepsilon q$. (1), we derive the determinants of growth rate of real GDP as the growth rates of labour force, $l$, capital stock, $k$, and aid stock, $a$, as shown below:

$$
y=\alpha+\beta l+\lambda k+\theta a
$$

Therefore, by comparing $\varepsilon q$. (1) and (2), the gross domestic product, $Y$, becomes the growth rate of GDP, $y$, labour input, $\mathrm{L}$, is replaced by the growth rates of labour force, $l$; domestic capital stock, $\mathrm{K}$, is replaced by the growth rate of capital stock, $k$, while the growth rate of aid stock replaces the foreign aid stock. Given the choice of variables, discussed earlier, it is then evident from Eq. (2) that the growth rate of GDP per capita is used as a proxy for the growth rate of GDP, the growth rate of labour force is $l$, gross capital formation as a percentage of GDP is $k$, and the share of total aid to GDP is $a$. The model to be estimated is therefore:

$$
G D P P C_{t}=\beta_{0}+\beta_{1} L B F_{t}+\beta_{2}\left(\frac{G C F}{G D P}\right)_{t}+\beta_{3}\left(\frac{O D A}{G D P}\right)_{t}+\varepsilon_{t}
$$

This model can thus be written as:

$$
G D P P C_{t}=\beta_{0}+\beta_{1} L B F_{t}+\beta_{2} C A P_{t}+\beta_{3} A I D_{t}+\varepsilon_{t}
$$

where GDPPC $C_{\mathrm{t}}$ is the rate of growth of real GDP per capita in time $t$, measured in current 2000 US\$; $\mathrm{LBF}_{\mathrm{t}}$ is the growth rate of total labour force; capital stock (CAP) is gross capital formation (GCF) as a share of GDP; and AID is the total ODA as a percentage of GDP. Our objective was to find the marginal effect of foreign aid on growth, and to determine whether $\beta_{3}$ was positive or negative and statistically significant. Although not the focus of this study, the expected effects of labour force $\beta_{1}$ can be either positive or negative, while those of capital stock $\beta_{2}$ are positive. Where labour force, as defined by World Bank Group (2011), includes people who are employed, those who are unemployed but seeking work and first-time job-seekers. Not everyone who works is included: unpaid workers, family workers and students are often omitted, while some countries do not count members of the armed forces. 


\subsection{Autoregressive Distributed Lag (ARDL)}

The ARDL in the bounds test approach, which was developed by Pesaran, Shin and Smith (2001), is based on estimating the model using the ordinary least square (OLS) method of the conditional unrestricted error correction model (UECM) for co-integration. It is used in determining the long-run relationship between variables and also to estimate the coefficients of the short- and long-run effects. Most time series data is non-stationary and ignoring this could result in spurious regression.

The co-integration between the variables in the production function was analysed using the ARDL. The advantage of using this method of co-integration is that, firstly, it is not subject to performing a pre-test for stationarity, nor is the order of integration required. It is, however, imperative that the variables be at most of order one I(1), not order two I(2). Other advantages of using the ARDL over and above other well-known methods of co-integration are that, secondly, the model has better statistical properties, and thirdly, it is still possible to carry out the estimation even when the explanatory variables are endogenous (Pesaran et al., 2001).

We therefore model Eq. (4) as a conditional ARDL as:

$$
\begin{aligned}
\triangle G D P P C_{t}=\phi_{0}+ & \sum_{i=1}^{m} \phi_{1 i} \Delta G D P P C_{t-i}+\sum_{j=0}^{n} \phi_{2 j} \Delta L B F_{t-j}+\sum_{k=0}^{p} \phi_{3 k} \Delta C A P_{t-k} \\
& +\sum_{l=0}^{q} \phi_{4 l} \Delta A I D_{t-l}+\psi_{1} G D P P C_{t-1}+\psi_{2} L B F_{t-1}+\psi_{3} C A P_{t-1} \\
& +\psi_{4} A I D_{t-1}+\varepsilon_{t}
\end{aligned}
$$

Here $\Delta$ denotes first difference, $t-1$ denotes one-period lag, $\sum_{i=1}^{m}$ denotes the sum of $i=1,2$, $3, \ldots m ; \sum_{j=0}^{n} \quad$ denotes the sum of $j=0,1,2, \ldots n ; \sum_{k=0}^{p}$ denotes the sum of $k=0,1,2, \ldots p$; and $\sum_{l=0}^{q}$ denotes the sum of $I=0,1,2, \ldots q$; the parameters $\phi_{\mathrm{i}}(i=1$ to 4$)$ capture the coefficients of the short-run dynamic and $\psi_{j}(j=1$ to 4$)$ gives the long-run estimates. The other variables are as defined above.

The co-integration equation is specified as:

$$
\psi_{1} G D P P C_{t-1}+\psi_{2} L B F_{t-1}+\psi_{3} C A P_{t-1}+\psi_{4} A I D_{t-1}=0
$$

The ARDL methodology requires examining the null hypothesis of a conditional or 'no conditional' relationship using the $F$-test, which tests the joint significance of the lagged levels of the variables $\operatorname{lnGDPPC}_{\mathrm{t}-1}, \operatorname{lnLBF}_{\mathrm{t}-1}, \mathrm{CAP}_{\mathrm{t}-1}$ and $\mathrm{AID}_{\mathrm{t}-1}$. This is the hypothesis of the long-run relationship:

$$
\begin{aligned}
& H_{0}: \psi_{1}=\psi_{2}=\psi_{3}=\psi_{4}=0 \\
& H_{1}: \psi_{1} \neq \psi_{2} \neq \psi_{3} \neq \psi_{4} \neq 0
\end{aligned}
$$

Pesaran et al. (2001) developed critical values for two bounds, namely the upper bound and lower bound. These apply when the variables are integrated of order one I(1) or when they are stationary $I(0)$. However, the critical values generated by Pesaran et al. (2001) are based on large samples of 500 and 1000 observations and 20000 and 40000 observations for I(0) and $\mathrm{I}(\mathrm{l})$, respectively. Narayan (2005) computed the critical values for small sample sizes ranging 
from 30-80 observations, which is applicable to the present study. The interpretation of the hypothesis testing is as follows: if at a chosen significant level the computed F-statistic obtained from the Wald test lies between the upper and lower bounds, there is no conclusive inference; if it exceeds the upper bound, we can reject the null hypothesis of no co-integration; but we cannot reject the null hypothesis if it lies below the lower bound.

The short-run effects are captured by the coefficients of the variables in their first differences as shown in $\mathbf{E q . ~ ( 5 ) , ~ w h i l e ~ t h e ~ l o n g - r u n ~ c o e f f i c i e n t s ~ a r e ~ o b t a i n e d ~ b y ~ f i r s t ~ m u l t i p l y i n g ~ t h e ~}$ coefficients of the one-period lag of the explanatory variables by a negative sign, then dividing by the coefficient of the one-period lag of the dependent variable. That is, the long-run coefficient of the growth rate of labour force is $-\left(\frac{\psi_{2}}{\psi_{1}}\right)$, the long-run coefficient of capital stock is $-\left(\frac{\psi_{3}}{\psi_{1}}\right)$, and the long-run coefficient of foreign aid is $-\left(\frac{\psi_{4}}{\psi_{1}}\right)$.

\section{EMPIRICAL RESULTS}

The unit root test using the Phillips-Perron (PP) test was carried out on all the variables and they were found to be integrated of order one, I(1). We could, therefore, continue to apply the UECM method. The results of the unit root test obtained are reported in TABLE 1.

TABLE 1: Summary of unit root tests: Phillips-Perron

\begin{tabular}{lcccc}
\hline \multirow{2}{*}{ Variables } & \multicolumn{2}{c}{ Levels } & \multicolumn{2}{c}{ First difference } \\
& Intercept & Trend \& Intercept & Intercept & Trend \& Intercept \\
\hline GDPPC & $-3.050 \star \star$ & $-3.374 *$ & $-5.846 \star \star \star$ & $-5.667 \star \star \star$ \\
LBF & -1.082 & -1.766 & $-5.552^{\star \star \star}$ & $-5.458 * \star \star$ \\
CAP & $-2.874 \star$ & -1.950 & $-5.795 * \star \star$ & $-9.158 \star \star \star$ \\
AID & -1.946 & -2.962 & $-12.247 \star \star \star$ & $-13.635 \star \star \star$ \\
\hline
\end{tabular}

Source: Author's analysis

$\star 10 \% ; \star \star 5 \% ; \star \star \star * 1 \%$.

A parsimonious model of UECM was first performed with the lag length of 1 for the differenced variables as selected by the entire lag length criteria (see appendix). Next the insignificant variables were gradually dropped, observing the increase or decrease in the Akaike information criterion in order to note the importance of the variables being dropped. The result of the estimation is reported in TABLE 2. As hypothesised, the coefficient of the capital stock, $\beta_{2}$, is positive and significant in the short run; this relationship becomes insignificant in the long run. The labour force and aid are found to be negatively related to per capita GDP growth, but insignificant only in the short run. 
TABLE 2: Estimated ARDL model for per capita GDP growth function

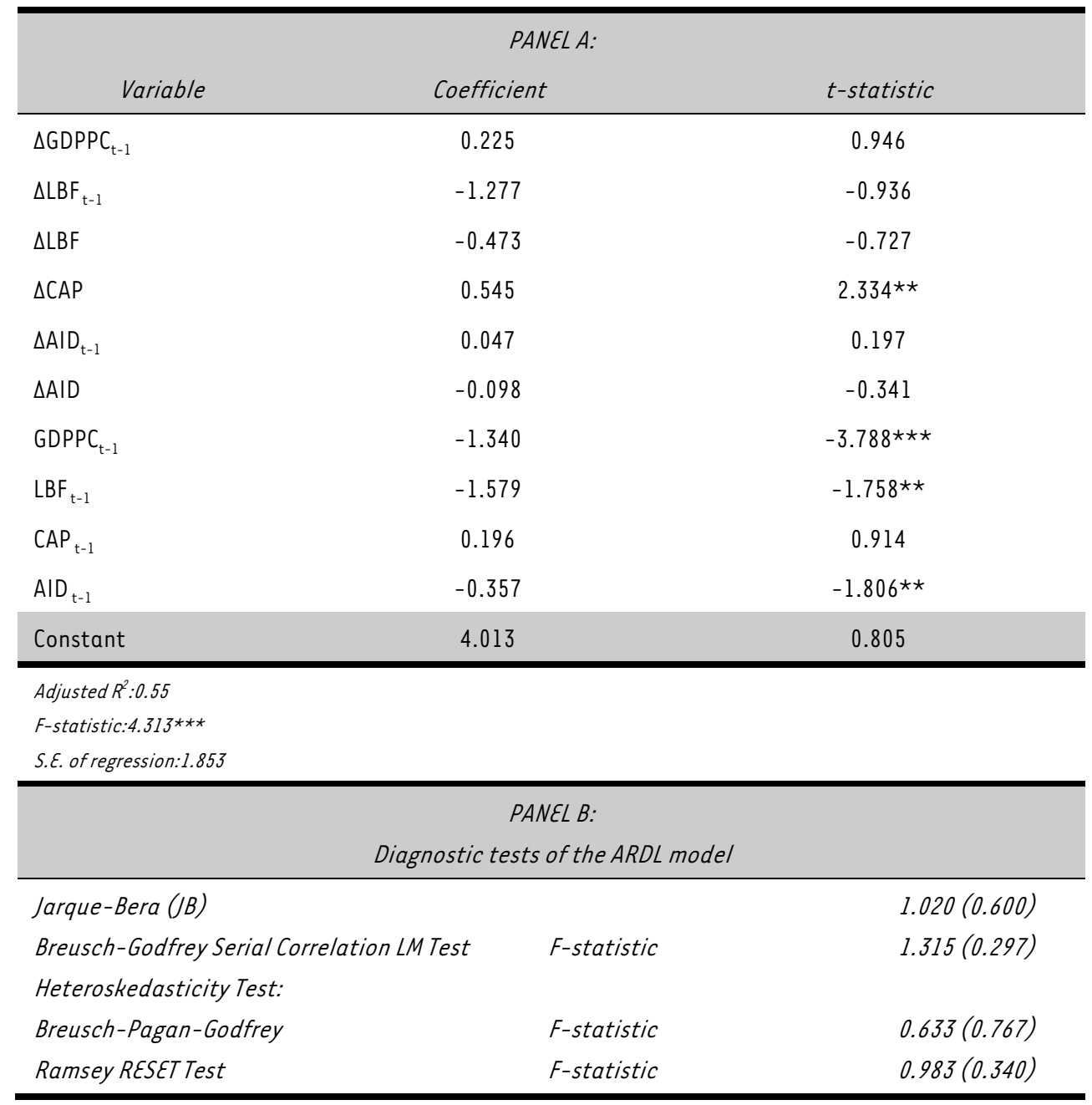

Source: Author's analysis

Figures in parentheses indicate $p$-values

The result of the relationship between aid and GDP per capita growth shows a small inverse effect of about $0.09 \%$ in the short run. The result of the long-run coefficients shows a marginal effect of -0.266 . This means that a percentage increase in foreign aid will cause per capita GDP to fall by about $0.27 \%$ in the long run. This is significant at the $5 \%$ and $10 \%$ levels. The adjusted $\mathrm{R}^{2}$ of $55 \%$ shows a good fit of the model. The result also passes the battery of diagnostic tests as shown in panel B of TABLE 2.

TABLE 3 shows that there is a long-run relationship between foreign aid and per capita GDP growth. The critical values obtained from Narayan (2005) show that the computed F-statistic exceeds the upper critical limit at the $10 \%$ and $5 \%$ levels. This implies that the null hypothesis of no co-integration among the series can be rejected. There is, therefore, a long-run relationship among all the variables. 
TABLE 3: Cointegration test results

\begin{tabular}{l|cc|c|c|cc}
\hline \multicolumn{7}{c}{ CRITICAL VALUE BOUNDS OF THE F-STATISTICS: } \\
restricted intercept and no trend \\
F-statistic & \multicolumn{2}{c}{$90 \%$ level } & \multicolumn{2}{c}{$95 \%$ level } & 99\% level \\
\hline $5.212^{* *}$ & $\mathrm{I}(0)$ & $\mathrm{I}(\mathrm{l})$ & $\mathrm{I}(0)$ & $\mathrm{I}(1)$ & $\mathrm{I}(0)$ & $\mathrm{I}(\mathrm{l})$ \\
& 2.676 & 3.586 & 3.272 & 4.306 & 4.614 & 5.966 \\
\hline
\end{tabular}

Source: Author's analysis

$n=30$

The number of regressors $(k)$ is 3 .

Critical values obtained from Narayan (2005), Case II, p.1987.

I(0) - lower bound;

(1) - upper bound.

\section{CONCLUSION}

One of the objectives of this study was to determine if there is a positive or negative relationship between foreign aid and per capita GDP growth, and if the relationship is statistically significant. The study further investigated the existence of a long-run relationship between these variables and, therefore, sought to determine the effect of foreign aid on growth both in the short and long run. The data on aid flow as a percentage of GDP in South Africa was only available from 1980. This, therefore, limited the data to the years 1980 to 2008.

The model, which explains the relationship between foreign aid and per capita GDP growth for South Africa, was estimated using the UECM framework. This model is suitable mainly when conducting co-integration analysis in small samples, as in this case. This is because it avoids the finite sample bias that static estimators are faced with, and it is more efficient than VAR methods.

Conventionally, the model is derived from a production function where foreign aid is introduced as an input. The variables considered are growth rate of GDP per capita, the growth rate of total labour force, gross capital formation as a share of GDP and the total ODA (aid) as a percentage of GDP. These were sourced from the World Bank World Development Indicators database. Firstly, the test for unit root was carried out on all the variables considered, using the Phillips-Perron test, and all the variables were found to be I(1). Secondly, the relationship between aid and growth was found to be negative both in the short and long run. However, this effect was only statistically significant in the long run, where the marginal effect shows a percentage increase in foreign aid resulting in a decline of about $0.27 \%$ in economic growth.

The reason for the negative relationship could be that, although the intention of foreign aid is to correct for inequalities in global income, aid used generally in targeting poverty particularly in South Africa during the first few years after apartheid achieved less. During this period, donor countries chose specific institutional targets for their aid because aid was used solely for changing existing institutions as well as building a new system of governance. As the period of post-apartheid crisis decreased, donors began to plan for other objectives such as promoting overall economic growth. 
It is evident that the impact of foreign aid on growth is conditional on the policies of the recipient countries, especially in cases where the aid money is not targeted towards specific goals. Therefore, countries with better policy regimes and low or no level of corruption experience a positive impact of aid on their economy. Although South Africa is not known for high levels of corruption, there is still evidence of significant corruption in the lower levels of government. This further shows that the foreign aid received in South Africa has not been channelled to individual needs, and hence its inverse effect on per capita GDP, as a proxy for GDP. Another reason could be that since South Africa is an upper-middle income country, its dependence on foreign aid has gradually declined and the country has further experienced a fall in poverty due to a reallocation of pro-poor expenditure on housing and water (UNDP, 2012). Further studies could consider disaggregated foreign aid as opposed to the total aid used in this study. The non-linearity of aid and time lags are other factors that could also be considered for further studies in testing the effect of aid on growth.

\section{LIST OF REFERENCES}

Banerjee, A., Dolado, J. Galbraith, J. \& Hendry, D. (1993). Co-integration, Error-Correction, and the Econometric Analysis on Non-Stationary Data. Oxford: Oxford University Press, Advanced Texts in Econometrics.

Brautigam, D.A. \& Knack, S. (2004). Foreign aid, institutions, and governance in Sub-Saharan Africa. Economic Development and Cultural Change, 52(2), pp. 255-285.

Chatterjee, S. \& Turnovsky, S.J. (2007). Foreign aid and economic growth: The role of flexible labor supply. Journal of Development Economics, 84, pp. 507-533.

CIA (Central Intelligence Agency). (2012). The World Factbook. [Online] Available: https://www.cia.gov/library/publications/the-world-factbook/geos/countrytemplate_sf.html. (Accessed 12 August 2012)

CMI (Chr. Michelsen Institute) (2003). Policy Brief, Development Aid to South Africa. March. Chr. Michelsen Institute. Development Studies and Human Rights, Norway.

Ekanayake, E.M. \& Chatrna, D. (2010). The effect of foreign aid on economic growth in developing countries. Journal of International Business and Cultural Studies, 3, pp. 1-13.

Feeny, S. (2005). The impact of foreign aid on economic growth in Papua New Guinea. Journal of Development Studies, 41(6), pp. 1092-1117.

Hansen, H. \& Tarp, F. (2000). Aid effectiveness disputed. Journal of International Development, 12(3), pp. 375-398.

Hatemi-J, A. \& Irandoust, M. (2005). Foreign aid and economic growth: New evidence from panel cointegration. Journal of Economic Development, 30(1), pp. 71-80.

Inder, B. (1993). Estimating long-run relationships in economics: A comparison of different approaches. Journal of Econometrics, 57(1), pp. 53-68.

Islam, A. (1992). Foreign aid and economic growth: An econometric study of Bangladesh”, Applied Economics, 24(5), pp. 541-544.

Karras, G. (2006). Foreign aid and long-run economic growth: empirical evidence for a panel of developing countries. Journal of International Development, 18(7), pp. 15-28. 
Lloyd, T., Morrissey, \& R. Osei, R. (2001). Aid, exports and growth in Ghana. CREDIT Research Paper, No. 01/01, pp. 1-47.

Mallik, G. (2008). Foreign aid and economic growth: A cointegration analysis of the six poorest African countries. Economic Analysis and Policy, 38(2), pp. 251-260.

May, T. (2006). Vague targets: The case of aid in South Africa. Harvard International Review, 28(2), p. 7.

Mbaku, J.M. (1994). Foreign aid and economic growth in Cameroon: A reply. Applied Economics Letters, 1(4), pp. 55-57.

Moreira, S.B. (2005). Evaluating the impact of foreign aid on economic growth: A cross-country study. Journal Of Economic Development, 30(2), pp. 25-49.

Narayan, P.K. (2005). The saving and investment nexus for China: Evidence from cointegration tests". Applied Economics, 37(17), pp. 1979-1990.

OECD (Organisation for Economic Cooperation and Development) (1997). Geographical Distribution of Financial Flows to Aid Recipients, Paris.

$0 \varepsilon C D$ (Organisation for Economic Cooperation and Development) (2006). Geographical Distribution of Financial Flows to Aid Recipients, 2000 - 2004, Paris.

OECD (Organisation for Economic Cooperation and Development) (2007). Geographical Distribution of Financial Flows to Aid Recipients, 2001 - 2005, Paris.

OECD (Organisation for Economic Cooperation and Development) (2010). Development Aid at a Glance: Statistics by Region, Africa 2010, Paris.

Pesaran, M.H., Shin, Y. \& Smith, R.J. (2001). Bounds testing approaches to the analysis of level relationships. Journal of Applied Econometrics, 16(3), pp. 289-326.

UNDP (United Nations Development Programme) (2010). Millennium Development Goals.

UNDP (United Nations Development Programme) (2012). MDGs in South Africa. [Online] Available: http://www.undp.org.za/millennium-development-goals/mdgs-in-south-africa. (Accessed 11 August 2012)

USAID (2010). USAID in South Africa. [Online] Available: http://sa.usaid.gov/south_africa/node/3. (Accessed 19 May 2011)

World Bank Group (2011). Labour and social protection. [Online] Available:

http://data.worldbank.org/topic/labor-and-social-protection. (Accessed 20 January 2011) 


\section{APPENDIX}

VAR Lag Order Selection Criteria

Endogenous variables: AID CAP LGGPC LGLBF

Exogenous variables: $C$

Sample: 19802009

Included observations: 27

\begin{tabular}{ccccccc}
\hline Lag & LogL & $L R$ & FPE & AIC & SC & $H \rho$ \\
\hline 0 & -63.01872 & NA & 0.001683 & 4.964350 & 5.156326 & 5.021434 \\
1 & 89.68065 & $248.8434 *$ & $6.85 \mathrm{e}-08 *$ & $-5.161530 \star$ & $-4.201650 \star$ & $-4.876107 \star$ \\
2 & 102.9288 & 17.66415 & $9.18 \mathrm{e}-08$ & -4.957686 & -3.229904 & -4.443926 \\
3 & 116.4086 & 13.97908 & $1.41 \mathrm{e}-07$ & -4.771007 & -2.275321 & -4.028908 \\
\hline
\end{tabular}

* indicates lag order selected by the criterion

LR: sequential modified LR test statistic (each test at $5 \%$ level)

FPE: Final prediction error

AIC: Akaike information criterion

SC: Schwarz information criterion

$\mathrm{HQ}$ : Hannan-Quinn information criterion 